\title{
Self-Reported Physician Adherence to Guidelines for Measuring Blood Pressure
}

\author{
Robert C. Dickson, Kathryn Gaebel, Angelo Zizzo, Ieva Neimanis, Margaret Bridge, \\ John Corsini, Cindy Goebel, Richard Levy, and Anne Woods
}

Background: Diagnosis of hypertension, treatment, and follow-up depend on accurate measurement. This research study attempted to determine whether family physicians are all measuring blood pressure (BP) according to Canadian guidelines.

Methods: A short survey was mailed to all physicians within the Department of Family Medicine, St. Joseph's Healthcare, Hamilton, Ontario, Canada.

Results: Fifty-one percent of the surveys were completed and returned. Eleven of the recommendations were followed "always or most of the time." BP is measured manually by $63 \%$ of the respondents, and the most frequent barrier to following the recommendations was time.

Conclusion: The results of the survey indicated that measurement of BP according to Canadian Hypertension Education Program recommendations was felt to be important and conducted in most cases, but there is room for improvement. ( $\mathrm{J}$ Am Board Fam Med 2013;26:215-217.)

Keywords: Blood Pressure, Family Physicians, Hypertension, Surveys

Accurate, reproducible measurement of blood pressure (BP) is critical when making decisions about patient care. Diagnosis of hypertension, treatment, and follow-up depend on accurate measurement. There are many effective medications to treat $\mathrm{BP}$, but their use assumes accurate measurement. The Committee on Utilization, Research and Education attempted to determine whether family physicians are measuring BP in the same way and according to Canadian guidelines.

The 2010 Canadian Hypertension Education Program (CHEP) included detailed recommendations ${ }^{1}$ for how BP should be measured. The Committee on Utilization, Research and Education developed a short survey to ascertain how the majority

This article was externally peer reviewed.

Submitted 3 February 2012; revised 18 October 2012; accepted 23 October 2012.

From the Department of Family Medicine (RCD, AZ, IN, $\mathrm{MB}, \mathrm{JC}, \mathrm{CG}, \mathrm{RL}, \mathrm{AW})$ and the Centre for Evaluation of Medicines (KG), St. Joseph's Healthcare, Hamilton, Ontario, Canada.

Funding: Unrestricted funding was received from Eli Lilly Canada, Inc., and Merck Canada, Inc.

Conflict of interest: none declared.

Corresponding author: Robert C. Dickson, Department of Family Medicine, St. Joseph's Healthcare, 50 Charlton Avenue East, Hamilton, Ontario, L8N 4A6 Canada (E-mail: rcdickson@sympatico.ca). of family physicians measure BP in their own practices and to determine whether it is practical to follow the guidelines.

\section{Methods}

Practicing community family physicians from the Department of Family Medicine, St. Joseph's Healthcare, Hamilton, Ontario, Canada, were invited by mail to participate. They were asked to identify the frequency (using a 5-point Likert scale) with which they followed 11 selected CHEP recommendations for measuring a patient's BP. They also were asked to identify which of the recommendations they deemed important as well as barriers to following the recommendations. They were asked who measured patient BP and how was it measured. Analysis was performed using IBM SPSS Statistics Base version 18.0 (IBM, Chicago, IL).

\section{Results}

Of 106 physicians invited to participate, 54 (51\%) returned the survey. BP measurement is a shared responsibility (physician/nurse/assistant) in 50\% of the family practices that responded. BP is measured manually in $63 \%$ of the offices and measurement is automated in $22 \%$ of the offices, whereas $15 \%$ use 
both. On average, 4 readings were taken when an automatic machine was used. One of the most frequent $(63 \%)$ barriers to following the recommendations was time.

The physician responses on the 5-point scale were collapsed into 3 response categories: "always or most of the time," "sometimes," and "rarely and never followed." As seen in Table 1, 8 of the 11 recommendations (A through $\mathrm{E}$ and $\mathrm{I}$ through $\mathrm{K}$ ) were reportedly followed "always or most of the time." Five of these items (C, E, I, J, and K) were not rated as important items to follow: their importance ratings varied between $9 \%$ and $39 \%$.

\section{Discussion}

The results of the survey indicated that measurement of BP according to CHEP recommendations was felt to be important and was conducted in most cases. It would seem that there is room for improvement. This may have been partially achieved in our department by simply completing the survey. The practicality of following all CHEP guidelines could be questioned. The importance or "weighting" of various guidelines should be clarified.

Although incorrect technique or inaccurate equipment may generate $\mathrm{BP}$ values that are consistent from time to time in a given office, these values may not be appropriate for therapeutic decision making and may not be comparable to values obtained by another observer in different circumstances, including self-measurement by patients at home.

Because there is a large number of medications to treat elevated $\mathrm{BP}$ and because guidelines seem to be suggesting lower and lower targets, resulting in the potential for defining more patients as hypertensive, it would seem critical that BP be measured accurately and reproducibly. Many environmental or procedural factors may change $\mathrm{BP}$ values as much as or more than medications. For example, as stated in the 2005 American Heart Association BP measurement recommendations, ${ }^{2}$ "The individual should be comfortably seated, with the legs uncrossed, and the back and arm supported, such that the middle of the cuff on the upper arm is at the

Table 1. Summary of Responses from 54 Physicians

\begin{tabular}{|c|c|c|c|c|c|c|}
\hline \multicolumn{2}{|r|}{ CHEP Recommendation } & \multirow{2}{*}{$\begin{array}{c}\text { Always/Most } \\
\text { Times } \\
50(93)\end{array}$} & \multirow{2}{*}{$\begin{array}{c}\text { Sometimes } \\
3(6)\end{array}$} & \multirow{2}{*}{$\begin{array}{c}\text { Rarely/Never } \\
1(2)\end{array}$} & \multirow{2}{*}{$\begin{array}{l}\text { Important } \\
35(65)\end{array}$} & \multirow{2}{*}{$\begin{array}{c}\text { Ratio (Importance } \\
\text { to Adherence) } \\
70\end{array}$} \\
\hline A & $\begin{array}{l}\text { Patient should be seated comfortably, back } \\
\text { supported, feet flat, and legs not crossed. }\end{array}$ & & & & & \\
\hline B & $\begin{array}{l}\text { Patient should be resting comfortably for } 5 \mathrm{~min} \text { in a } \\
\text { seated position before measuring BP. }\end{array}$ & $42(78)$ & $9(17)$ & $3(6)$ & $31(57)$ & 74 \\
\hline $\mathrm{C}$ & $\begin{array}{l}\text { The patient's arm should be bare and supported at } \\
\text { heart level. }\end{array}$ & $44(82)$ & $8(15)$ & $2(4)$ & $21(39)$ & 48 \\
\hline $\mathrm{D}$ & $\begin{array}{l}\text { A cuff appropriate to the size of the patient's arm } \\
\text { should always be used. }\end{array}$ & $54(100)$ & 0 & 0 & $32(59)$ & 59 \\
\hline $\mathrm{E}$ & $\begin{array}{l}\text { There should be no talking and legs should not be } \\
\text { crossed. }\end{array}$ & $47(87)$ & $5(10)$ & $2(4)$ & $21(38)$ & 45 \\
\hline $\mathrm{F}$ & $\begin{array}{l}\text { At least } 3 \text { measurements should be taken, no oftener } \\
\text { than } 1 \text { min apart. }\end{array}$ & $20(37)$ & $17(32)$ & $16(30)$ & $14(26)$ & 70 \\
\hline G & $\begin{array}{l}\text { BP should also be measured with the patient } \\
\text { standing for } 2 \text { minutes, with arm supported. }\end{array}$ & $3(6)$ & $9(17)$ & $40(74)$ & $1(2)$ & 33 \\
\hline $\mathrm{H}$ & $\begin{array}{l}\text { Reading should be taken at least once on both arms. } \\
\text { If one arm gives a considerably higher reading, } \\
\text { that arm should be used for future measurements. }\end{array}$ & $16(30)$ & $14(26)$ & $23(43)$ & $6(11)$ & 38 \\
\hline I & $\begin{array}{l}\text { Pressure should be rapidly increased to } 30 \mathrm{~mm} \\
\text { above the point at which the radial pulse } \\
\text { disappears. }\end{array}$ & $39(72)$ & $8(15)$ & $7(13)$ & $9(17)$ & 23 \\
\hline $\mathrm{J}$ & $\begin{array}{l}\text { Cuff deflation rate should be } 2 \mathrm{mmHg} \text { per heart } \\
\text { beat. }\end{array}$ & $36(71)$ & $9(18)$ & $6(12)$ & $5(9)$ & 16 \\
\hline & $\begin{array}{l}\text { In the case of arrhythmia, additional readings should } \\
\text { be taken. }\end{array}$ & $44(82)$ & $8(15)$ & $2(4)$ & $10(19)$ & 5 \\
\hline
\end{tabular}

Values provided as $\mathrm{n}(\%)$.

BP, blood pressure; CHEP, Canadian Hypertension Education Program. 
level of the right atrium (the mid-point of the sternum)." Disregarding this factor can cause a systematic error in blood pressure readings of as much as $10 \mathrm{~mm} \mathrm{Hg}^{3}$

\section{References}

1. Quinn RR, Hemmelgarn BR, Padwal RS, et al; Canadian Hypertension Education Program. The 2010 Canadian Hypertension Education Program recommendations for the management of hypertension: part I - blood pressure measurement, diagnosis and assessment of risk. Can J Cardiol 2010; 26:241-8.
2. Pickering TG, Hall JC, Appel LJ, et al, Subcommittee of Professional and Public Education of the American Heart Association Council on High Blood Pressure Research. Recommendations for blood pressure measurement in humans and experimental animals: Part 1: blood pressure measurement in humans: a Statement for Professionals from the Subcommittee of Professional and Public Education of the American Heart Association Council on High Blood Pressure Research. Hypertension 2005;45: $142-61$.

3. Netea RT, Lenders JW, Smits P, Thien T. Arm position is important for blood pressure measurement. J Hum Hypertens 1999;13:105-9. 